\title{
FEATURES OF VIOLATIONS OF THE STATE OF THE VAGINAL ECOSYSTEM IN PREGNANT WOMEN WITH BACTERIAL VAGINOSIS
}

DOI: 10.36740/WLek202103114

\author{
Iryna M. Shcherbina, Iryna Yu. Plakhotna \\ KHARKIV NATIONAL MEDICAL UNIVERSITY, KHARKIV, UKRAINE
}

\begin{abstract}
The aim: To assess the condition of the vaginal ecosystem in pregnant women with BV.

Materials and methods: The main group consisted of 60 pregnant women with BV in the II trimester. The bacterioscopic examination, of vaginal smears was carried out. DNA diagnostics of the microbial spectrum of vaginal contents was performed. Bacteria with biofilm were visualized by fluorescence hybridization in situ.

Results: Biofilms were found in 25 women (41.65\%) of the main group, the main component of which was bacteria belonging to the Gardnerella cluster at a concentration of $7.9 \pm 0.13 \mathrm{log}$ CFU/g. Atopobium vagine cluster bacteria gave positive hybridization signals in more than half of the patients and amounted to $6.8 \pm 0.15 \mathrm{lg}$ CFU $/ \mathrm{g}$. In addition, Snethia spp. was determined as a part of the biofilm at a concentration of $5.8 \pm 0.3 \mathrm{lg} \mathrm{CFU} / \mathrm{g}$.

Conclusions: Thus, the use of the proposed treatment regimen for women with vaginal dysbiosis led to the elimination of pathogenic and conditionally pathogenic microflora. However, the effectiveness of treatment in 5 cases was lower than expected, which indicates the emergence of bacterial resistance.
\end{abstract}

KEY WORDS: dysbiosis, biofilms, pregnancy

Wiad Lek. 2021;74(3 p.l):460-464

\section{INTRODUCTION}

Currently, the structure of genital infections in pregnant women is dominated by violations of the vaginal microbiocenosis. Pregnancy itself is a risk factor for the development of pathology caused by opportunistic microflora and microorganisms with weak virulence and aggression factors which leads to the occurrence of bacterial vaginosis (BV).BV in pregnant women is associated with an increase of obstetric complications and occurs with a frequency of up to $30 \%-50 \%$ [1].

The microecosystem of the vagina during a physiologically ongoing pregnancy is a dynamic self-regulating biological system characterized by colonial and nonspecific resistance, as well as biochemical parameters that reflect its metabolic activity [2,3].There is still no single view on the problem of the influence of hormonal changes during pregnancy on the quantitative and qualitative composition of microorganisms. Under the influence of corpus luteum hormones, the vaginal mucosa thickens, the elasticity of the cells of the intermediate layer increases, the synthesis of glycogen increases in them, and favorable conditions for the vital activity of lactobacilli are created $[4,5]$.

According to other authors, during pregnancy, when hormonal status is rearranged towards the prevalence of gestagens and under their influence the secretion of cervical mucus changes the $\mathrm{pH}$ level increases, which leads to a change in the vaginal microflora and the propagation of opportunistic microflora, which is characteristic of the norm, but with an increase in the population it can cause all kinds of unpleasant phenomena and the development of inflammatory processes [6].

The main problem with bacterial vaginosis is that the vagina is easily infected with pathogenic microflora and BV passes into vulvovaginitis. Ascending infection of the genital tract provokes inflammation of the membranes, in the event of which the risk of complications increases several times [7].In this way, the high prevalence of BV in pregnant women make it an important public health problem. The etiopathogenesis of BV has not yet been fully studied and is still the subject of controversy due to the great diversity and complexity of the microorganisms involved; therefore, effective approaches to predicting outcomes and treating this infection are limited $[8,9]$. The standard regimens recommended for prophylaxis and treatment allow to achieve cure only in $60-70 \%$ of cases. This is due to the fact that $\mathrm{BV}$ is characterized not only by excessive bacterial growth, but also by the presence of a dense bacterial biofilm tightly attached to the mucous membrane of the vagina, which is an obligate sign of BV and is absent in healthy women $[9,10]$. Gardnerella vaginalis is known to be involved in the formation of biofilms on the vaginal epithelium. The primary attachment of Gardnerella to the vaginal epithelium serves as a framework for the attachment of other types of bacteria with a high degree of adhesion, cytotoxicity and the ability to form biofilms. Such biofilms contain bacteria enclosed in the intercellular matrix of polymer compounds that they synthesize immediately after adhesion -lipopolysaccharides, proteoglycans, endopolysaccharides, and have 
altered physiological properties that betray them resistance to antibiotics and immune defense factors $[11,12]$.

Currently, there are various therapeutic strategies for combating biofilm infections. This is the use of antiseptics, natural antimicrobials, DNAse, plant compounds, prebiotics and probiotics, as well as acidification of the vagina to prevent recurrence of bacterial vaginosis [13].

There is no clear algorithm for treating bacterial vaginosis and its complications. Therefore, one should look for promising new methods of treating BV aimed at eliminating the pathogen, restoration of $\mathrm{pH}$ and colonization by strains of normal vaginal microflora [14].

It has been established that certain strains of Lactobacillus can act as probiotics, preventing the growth of bacteria associated with BV through two main mechanisms: inhibiting the adhesion of pathogens to the vaginal epithelium and the production of antimicrobial compounds such as hydrogen peroxide, lactic acid and bacteriocins $[15,16]$. Antiseptics are also used to treat vaginal infections. They have antibacterial activity against a wide range of bacteria, acting by nonspecific destruction of their cell membrane [11].

\section{THE AIM}

The assessment of the state of the vaginal ecosystem in pregnant women with $\mathrm{BV}$, as well as to study the clinical effectiveness of the therapy with the proposed method and to establish a possible cause of treatment failure.

\section{MATERIALS AND METHODS}

The main group consisted of 60 pregnant women with BV and 10 women with a physiological course of gestation and childbirth. When selecting patients, the totality of signs that determined the state of the vaginal microbiocenosis as a nosological form of BV using the Amsel criteria was taken into account: the presence of "key" epithelial cells, whites, vaginal $\mathrm{pH}>4.6$; A positive amine test was determined when a fishy odor appeared after applying a drop of a $10 \%$ potassium dioxide $(\mathrm{KOH})$ solution to a sample of vaginal discharge [17]. Attention was drawn to the presence of a massive microflora content, the prevalence of morphotypes of Gardnerella vaginalis and obligate anaerobic bacteria (Eubacterium spp., Atopobium vaginae, Snethia spp., Megasphera spp., Peptostreptococcus spp., Lachnobacterium spp.)

The examination was carried out in the II trimester. The study of microbiocenosis included the determination of the qualitative and quantitative composition of vaginal bacteria. For bacterioscopic examination, the material from the vagina was taken with a sterile instrument and transferred to glass. Then we prepare smears subsequently stained by Gramand carried out microscopy using the immersion system. The presence of leukocytes and the degree of seeding by microorganisms were determined. For microbiological research, the material was taken from the vagina with a universal probe. The working part of the probe containing the test material was cut off and placed in a disposable
Eppendorf tube with a preservative solution. The presence of bacteria in the test material was confirmed by real-time PCR on a DT-96 instrument (SPU «DNA-Technology», Moscow) with the «Femoflor-16» test system. DNA diagnostics of the microbial spectrum of the vaginal contents was carried out before and after the local correction of vaginal dysbiosis with the classification of the microbial spectrum according to Boldyreva M.N., 2010[18].

Bacteria from the biofilm were visualized using in situ fluorescence hybridization based on 16/23 S ribosomal DNA (rDNA). The material for the study was a biopsy from the lateral wall of the middle section of the vaginal fornix (1-3 $\mathrm{mm}$ in diameter) with its subsequent fixation and obtaining paraffin blocks. Microtome sections were examined by the FISH method using a variety of probes. Vaginal biopsies were studied before treatment and a week after. For each patient, bacterial biofilm diversification (relative microbial cluster content of different strains) and biofilm permeability (indicator of microbial activity) were evaluated using the ThermoBrite ${ }^{\mathrm{Tw}}$ system in combination with VP 2000 [19].

Pregnant women with moderate and severe dysbiosis were divided into I $(\mathrm{n}=41)$ and II $(\mathrm{n}=19)$ clinical groups, respectively. In order to eliminate pathogenic microflora and normalize the condition of the vaginal ecosystem sanitation of the birth canal was carried out by irrigation of the vaginal mucosa with a broad-spectrum foaming antiseptic agent, which included chlorhexidine, hexamidine and chlorocresol 2 times a day with a diluted $1 / 10$ solution within 7 days.

To update the vaginal microflora, a combination of the bacteria Lactobacillus acidophilus and estriol was used, 1 vaginal tablet daily, 12 days.

Efficiency assessment was carried out on the basis of the above research methods. Statistical processing was performed using the program Statistica for Windows (version 8.0). To compare groups by quantitative variables, parametric analysis of variance (ANOVA) was used, and by qualitative variables, Pearson $\chi 2$ criterion was used. Differences were considered statistically significant at $p<0.05$.

Described in the publication research methods have been applied with respect to human rights in accordance with the existing ones in Ukraine legislation that meets international ethical requirements and does not violate ethical standards in science and standards for biomedical research, according to the conclusions of the ethics committee of Kharkiv National Medical University

\section{RESULTS}

When analyzing the data of bacteriological studies of the vaginal contents of women in the studied groups, it was found that the presence of an infectious process is accompanied by the formation of dysbiosis, the severity of which depends on the etiological factor and is characterized by varying degrees of decrease in lactobacilli, even to their complete absence against the background of the dominance of opportunistic microflora, both in the form of monocultures and microbial associations. 
Table I. Microbial spectrum of vaginal microbiocenosis in women with bacterial vaginosis before and after treatment (Tab. I)

\begin{tabular}{|c|c|c|c|c|c|c|}
\hline \multirow{2}{*}{$\begin{array}{l}\text { Microflora } \\
\text { lg CFU / g }\end{array}$} & \multicolumn{6}{|c|}{ Studygroups } \\
\hline & $\begin{array}{l}\text { Igroup } \\
\text { before treatment }\end{array}$ & $\begin{array}{l}\text { I group } \\
\text { after treatment }\end{array}$ & $\rho$ & $\begin{array}{l}\text { II group } \\
\text { before treatment }\end{array}$ & $\begin{array}{l}\text { II group } \\
\text { after treatment }\end{array}$ & $\rho$ \\
\hline E.coli & $3,2 \pm 0,12$ & $2,2 \pm 0,02$ & $<0,05$ & $4,3 \pm 0,1$ & $3,8 \pm 0,14$ & $<0,05$ \\
\hline Klebsiella spp. & $2,8 \pm 0,13$ & $2,1 \pm 0,04$ & $<0,05$ & $3,6 \pm 0,2$ & $2,9 \pm 0,12$ & $<0,05$ \\
\hline Candida spp. & $3,6 \pm 0,2$ & $2,4 \pm 0,1$ & $<0,05$ & $4,3 \pm 0,1$ & $2,1 \pm 0,05$ & $<0,05$ \\
\hline S.aureus & $2,9 \pm 0,13$ & $2,3 \pm 0,02$ & $<0,05$ & $3,3 \pm 0,01$ & $2,9 \pm 0,02$ & $<0,05$ \\
\hline Streptococcus spp. & $3,3 \pm 0,1$ & $2,2 \pm 0,13$ & $<0,05$ & $3,8 \pm 0,03$ & $2,4 \pm 0,12$ & $<0,05$ \\
\hline Gardnerella vaginalis & $5,6 \pm 0,13$ & $3,1 \pm 0,08$ & $<0,05$ & $6,9 \pm 0,13$ & $3,5 \pm 0,02$ & $<0,05$ \\
\hline Atopobium vaginae & $3,4 \pm 0,15$ & $2,2 \pm 0,12$ & $<0,05$ & $5,4 \pm 0,15$ & $2,8 \pm 0,05$ & $<0,05$ \\
\hline Mobiluncus spp. & $2,6 \pm 0,2$ & $1,3 \pm 0,2$ & $<0,05$ & $4,6 \pm 0,12$ & $2,4 \pm 0,02$ & $<0,05$ \\
\hline Snetia spp. & $3,1 \pm 0,12$ & $1,6 \pm 0,09$ & $<0,05$ & $4,9 \pm 0,05$ & $3,1 \pm 0,2$ & $<0,05$ \\
\hline Eubacterium spp. & $4,9 \pm 0,14$ & $2,4 \pm 0,13$ & $<0,05$ & $6,2 \pm 0,13$ & $3,6 \pm 0,13$ & $<0,05$ \\
\hline Megasphera spp. & $4,0 \pm 0,2$ & $2,7 \pm 0,05$ & $<0,05$ & $4,6 \pm 0,12$ & $3,3 \pm 0,08$ & $<0,05$ \\
\hline Lachnobacterium spp. & $3,5 \pm 0,15$ & $2,8 \pm 0,07$ & $<0,05$ & $4,8 \pm 0,21$ & $2,3 \pm 0,16$ & $<0,05$ \\
\hline Peptostreptococcus spp. & $5,0 \pm 0,2$ & $2,5 \pm 0,1$ & $<0,05$ & $6,3 \pm 0,13$ & $3,4 \pm 0,12$ & $<0,05$ \\
\hline
\end{tabular}

A bacteriological study of the control group revealed that in $97 \%$ of women, the composition of the vaginal microflora corresponded to normal indicators - the average number of lactobacilli was $(7.8 \pm 0.3) \lg \mathrm{CFU} / \mathrm{g}$. In some women $(3 \%)$, the concentration of lactobacilli was slightly reduced to (4.6 $\pm 0.2) \lg$ CFU / g. In isolated cases, E. coli, opportunistic staphylococci and streptococci, as well as Candida, were founded.

In the I group of women with a moderate dysbiosis a decrease in the concentration of lactobacilli was noted below $10^{7} \mathrm{CFU} / \mathrm{g}$ and amounted to an average of $6.5 \pm 0.14 \mathrm{lg}$ $\mathrm{CFU} / \mathrm{g}$. The main obligate anaerobic organisms turned out to be at a concentration of $5.6 \pm 0.13 \mathrm{lg} \mathrm{CFU} / \mathrm{g}$ and Atopobium vaginae at a concentration of $3.4 \pm 0.15 \mathrm{lg} \mathrm{CFU} / \mathrm{g}$. Part of the women examined identified bacteria of the genus Mobiluncus - $2.6 \pm 0.2 \mathrm{lg}$ CFU / g, Eubacterium-4.9 \pm $0.14 \mathrm{lg}$ CFU / g, Snethia - 3.1 $\pm 0.12 \mathrm{lg}$ CFU / g, Peptostreptococcus- $5.0 \pm 0.2 \mathrm{lg}$ CFU / g, Megasphera $-4.0 \pm$ $0.2 \mathrm{lg}$ CFU / g, Lachnobacterium spp. $-3.5 \pm 0.15 \mathrm{lg}$ CFU / g. The vaginal microflora of women of group II with severe dysbiosis was characterized by a variety of opportunistic microorganisms, that formed microbial associations, among which the most frequent were Gardnerella vaginalis, Atopobium vaginae and Snethia spp. in concentration 6,9 \pm

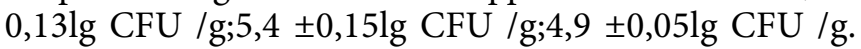
respectively. At the same time lactobacilli were completely absent in $88,8 \%$ of the examined patients of this group and their concentration in the rest was sharply reduced to $10^{2} \mathrm{CFU} / \mathrm{g}$ and averaged $1.3 \pm 0.16 \mathrm{lg}$ CFU / g. (Table I).

The biofilms were found in $25(41,6 \%)$ women of the main group: 14 pregnant women with moderate imbalance and 11 with severe dysbiosis. Gardnerella vaginalis was the main component of biofilms in a concentration (7.9 \pm $0.13 \mathrm{lg} \mathrm{CFU} / \mathrm{g})$. Atopobium vaginae gave positive hybridization signals in more than half of the patients $(6.8 \pm 0.15 \mathrm{lg}$ CFU/g). In addition, Snethia spp. was determined as part of the biofilm with concentration $(5.8 \pm 0.03 \mathrm{lg} \mathrm{CFU} / \mathrm{g})$. At the same time, the presence of the $G$. vaginalis and Megasphaera sp. community, which are usually identified during BV, was a criterion at for the absence of biofilms; therefore, the presence of Gadnerella vaginalis is not always accompanied by the formation of a biofilm with a violation of the vaginal microflora. Bacteria of the Lactobacilli and Bacteroides clusters were present in less than half of women and made up a small fraction of the biofilm.

After complex therapy of bacterial vaginosis, a bacteriological study of the vaginal contents in women of the studied groups was carried out.

In group I, after treatment, an increase in colonization with lactobacilli species was observed up to $10^{4}-10^{5} \mathrm{CFU} / \mathrm{g}$. Initially, high colonization by bacteria of the genus Gardnerella vaginalis decreased to $3.1 \pm 0.08 \mathrm{lg} \mathrm{CFU} / \mathrm{g}$, and Atolium vaginae to $2.2 \pm 0.12 \mathrm{lg}$ CFU / g, Snethiaspp. $-1.6 \pm$ $0.09 \mathrm{lg}$ CFU / g, Mobiluncus - $1.3 \pm 0.2 \mathrm{lg}$ CFU / g, Eubacterium-2.4 $\pm 0.13 \mathrm{lg}$ CFU / g, Peptostreptococcus $-2.5 \pm 0.1 \mathrm{lg}$ CFU / g, Megasphera- $2.7 \pm 0.05 \mathrm{lg}$ CFU / g, Lachnobacterium spp. $-2.8 \pm 0.07 \mathrm{lg} \mathrm{CFU} / \mathrm{g}$.

In group II, after treatment, the degree of colonization by Candida fungi decreased by more than half and amounted to $2.1 \pm 0.05 \mathrm{lg} \mathrm{CFU} / \mathrm{g}$. A tendency towards the renewal of normobiocenosis due to increased colonization by lactic acid bacteria up to $10^{3}-10^{4} \mathrm{CFU} / \mathrm{g}$ (3.3 $\pm 0.07 \mathrm{lg}$ CFU / g on the average), which in most cases were completely absent before the start of therapy was also identified. The number of opportunistic anaerobes such as Gadnerella vaginalis, bacteria of the genus Mobiluncus spp., Atopolium vaginae, Snethia spp. and their associations in some women also decreased significantly: $3.5 \pm 0.02 \mathrm{lg} \mathrm{CFU} / \mathrm{g}, 2.4 \pm 0.02 \mathrm{lg} \mathrm{CFU} / \mathrm{g}$, $2.8 \pm 0.05 \mathrm{lg}$ CFU / g, 3.1 $\pm 0.2 \mathrm{lg}$ CFU / g respectively. Biofilms were not detected when combining G. vaginalis and Megasphaera. (Table I) amounted to an average. 


\section{DISCUSSION}

In more than half of the patients, the main component of the biofilm was bacteria belonging to the Gardnerella cluster and bacteria of the Atopobium cluster. In addition, Snethia $s p p$. was determined in most cases as part of the biofilm. The presence of such a community of microorganisms can be considered a sign of biofilm [20]. According to the results of the study, Gadnerella vaginalis is not always accompanied by the formation of a biofilm with a violation of the vaginal microflora, since with the combination of $G$. vaginalis and Megasphaera no biofilms have been identified [21]. In addition, it should be noted that there was a tendency to increase the number of opportunistic microorganisms in the medium to $10^{5-7} \mathrm{CFU} / \mathrm{g}$, which is also possibly one of the markers of biofilm formation [22]. Unfortunately, the treatment efficiency was lower than expected in some cases. We were not able to significantly improve the condition of the vaginal microbiota in 5 pregnant women, which indicates the persistence of vaginal ecosystem disturbances and the emergence of bacterial resistance (the presence of biofilms).

\section{CONCLUSIONS}

Thus, the use of the proposed treatment regimen for women with dysbiosis of the vaginal microflora led to the elimination of pathogenic and conditionally pathogenic microflora and promoted the colonization of the vaginal mucosa with lactobacilli. However, in some cases, the effect of the treatment was lower than expected. Therefore, the need to revise the standards for the diagnosis and treatment of bacterial vaginosis is obvious.

In our opinion, a promising method of treatment is the use of cavitated solutions (drug solutions treated with low-frequency ultrasound), the main advantage of which is an additional mechanical effect on the tissues, which contributes to the destruction of bacterial films, cleansing of the pathological substrate and trophic improvement. Our further research will be devoted to this topic.

\section{REFERENCES}

1. Nitsovych I.R., Semeniak A.V. Osoblyvosti perebihu ta likuvannia bakterialnoho vahinozu. [Features of the course and treatment of bacterial vaginosis]. Neonatology, surgery and perinatal medicine. 2016; 3:61- 64. (In Ukranian).

2. Lakhtin M.V., Lakhtin V.M., BajrakovaA.L. et al. Mul'tiuzlovaya konczepczi ya mikrobioczenoza biotopa cheloveka. [Multinodular microbiocenosis concept of human biotope]. Clinical laboratory diagnostics. 2015; 9:83-85. (In Russian).

3. Sinyakova A.A. Sovremennyie predstavleniya o mikrobiotsenoze vlagalischa i ego vliyanii na ishodyi beremennosti. [Current understanding of vaginal microbiocenosis and its impact on pregnancy outcomes]. Journal of Obstetrics and Women's Diseases. 2017; 66(6):89100. (In Russian).

4. Klymniuk S.Sh., Mykhailyshyn H.I., Malanchuk L.M. Mikrobiolohichni osoblyvosti bakterialnykh vahinoziv u zhinok riznykh vikovykh katehorii ta shliakhy yikh mikrobiolohichnoi korektsii [Microbiological features of bacterial vaginosis in women of different ages and ways of their microbiological correction]. Achievements of clinical and experimental medicine. 2019;3: 21-31. (In Ukranian) .
5. RishhukS.V. Disbioz vlagalishha: novy j j vzglyad na problemu. [Dysbiosis of the vagina: a new look at the problem]. Issues of gynecology, obstetrics and perinatology. 2016;3(15):54-63. (In Russian).

6. Mayorov M.V., Zhuperkova E.A., Zhuchenko S.I. Vaginalnyiy biotsenoz. Sovremennyie predstavleniya o norme i patologii [Vaginal biocenosis. Modern ideas about norm and pathology]. Medical aspects of women's health. 2017; 1:33 - 40. (In Russian).

7. Dubossarskaya Yu.A., Lebedyuk V.V. Optimizacziya taktiki vedeniya beremennostis czel' yu profilaktiki prezhdevremenny' kh rodov.[Optimization of tactics of pregnancy management for the purpose of prevention of premature birth]. Woman's health. 2016; 2:20-24. (In Russian).

8. Machado A., Cerca N. Influence of Biofilm Formation by Gardnerella vaginalis and Other Anaerobes on Bacterial Vaginosis. J Infect Dis. 2015; 212 (12):1856-1861.

9. Shalepo K.V., Mikhajlenko T.G., Savicheva A.M. Rol` bakterial'ny' kh plenok v formirovanii khronicheskikh patologicheskikh proczessov vo vlagalishhe ie ndometrii. [The role biofilms in the formation of chronic pathological processes in the vagina and endometrium]. Journal of Obstetrics and Women's Diseases. 2016; 4:70-75. (In Russian).

10. Alves P., Sousa C., Cereija T. Using an in vitro biofilm model to assess the virulence potential of Bacterial Vaginosis or non-Bacterial Vaginosis Gardnerella vaginalis isolates. Sci Rep. 2015; 5: 640-643.

11. Storchak A.V., Grishhenko O.V. Problemny'e voprosy` vosstanovleniya bioczenoza vlagalishha. [ Problematic issues of restoration of the vaginal biocenosis]. Women's health. 2015; 1: 52-60. (In Russian).

12. Verstraelen H., Swidsinski A. The biofilm in bacterial vaginosis: implications for epidemiology, diagnosis and treatment. Curr Opin Infect Dis. 2019; 32(1): 38-42.

13. Machado D., Castro J., Palmeira-de-Oliveira A. et al. Bacterial Vaginosis Biofilms: Challenges to Current Therapies and Emerging Solutions. Front Microbiol. 2015; 6:1528.

14. Karukkupalayam R., Bennur S., Nacimuthu G. Prenatal probiotics: The way forward in prevention of preterm birth. Journal of Clinical Gynecology and Obstetrics. 2019; 3:63-69.

15. Hardy L., Jespers V., Abdellati S. A fruitful alliance: the synergy between Atopobium vaginae and Gardnerella vaginalis in bacterial vaginosisassociated biofilm. Sex Transm Infect. 2016; 92 (7): 487-491.

16. Tovstanovskaya V.A., Alatorskih A.E., Faranak Parsay Otsenka mikrofloryi vlagalischa s bakterialnyim vaginozom posle provedennogo lecheniya s tselyu opredeleniya ego effektivnosti [Assessment of vaginal microflora with bacterial vaginosis after treatment to determine its effectiveness]. Women's Health. 2017; 1:154-159. (In Russian).

17. Machado A., Cerca N. Influence of Biofilm Formation by Gardnerella vaginalis and Other Anaerobes on Bacterial Vaginosis. I Infect Dis. 2015; 212(12):1856-1861.

18. Nazarova V.V., Shipitsyina E.V., Shalepo K.V. Bakterialnyie soobschestva,formiruyuschie mikroekosistemu vlagalischa v norme i pri bakterialnom vaginoze [Bacterial Communities Forming the Vaginal Microecosystem in Health and Bacterial Vaginosis]. Journal of Obstetrics and Women's Diseases 2017; 66(6):30-42. (In Russian).

19. Machado D., Castro J., Cereija T. et al. Diagnosis of bacterial vaginosis by a new multiplex peptide nucleic acid fluorescence in situ hybridization method. Peer J. 2015; 3:780.

20. Mendling W., Palmeira-de-Oliveira A., Biber S. et al. An update on the role of Atopobium vaginae in bacterial vaginosis: what to consider when choosing a trearment? Arch Gynecol Obstet. 2019; 300(1): 1-6.

21. Vestby L.K., Torstein G., Roger S. et al. Bacterial Biofilm and its role in the pathogenesis of disease. Antibiotics. 2020; 9:59. 
22. Pestrikova T.Yu., Yurasova E.A., Kotelnikova A.V. Sovremennyie podhodyi $k$ verifikatsii diagnoza bakterialnogo vaginoza i taktike vedeniya [Modern approaches to verification of the diagnosis of bacterial vaginosis and management tactics]. Mother and child. 2018; 2: 48-53. (In Russian).

\section{ORCID and contributionship:}

Iryna M. Shcherbina: 0000-0001-7666-8953 A,B,E,F

Iryna Yu. Plakhotna: 0000-0002-9101-9588 ${ }^{A, D}$

\section{Conflict of interest:}

The Authors declare no conflict of interest.

\section{CORRESPONDING AUTHOR}

Iryna Yu. Plakhotna

Kharkiv National Medical University

4 Prospect Nauki, 61057 Kharkiv, Ukraine

tel: +380668235549

e-mail: i.plakhotnaja@gmail.com

Received: 24.03 .2020

Accepted: 17.11 .2020

A - Work concept and design, B - Data collection and analysis, C - Responsibility for statistical analysis,

$\mathbf{D}$-Writing the article, $\mathbf{E}$-Critical review, $\mathbf{F}$ - Final approval of the article 